\title{
The impact of the corruption on the sustainable development of the businesses in South-West Bulgaria
}

\author{
Vladislav Krastev ${ }^{1}$, Blagovesta Koyundzhiyska-Davidkova ${ }^{2}$, and Irina Atanasova, ${ }^{3, *}$ \\ ${ }^{1}$ South-West University "Neofit Rilski", Department of Economics, Bulgaria \\ ${ }^{2}$ South-West University "Neofit Rilski", Department of Economics, Bulgaria \\ ${ }^{3}$ South-West University "Neofit Rilski", Department of Economics, Bulgaria
}

\begin{abstract}
Corruption as a phenomenon can be found in every country and society. It accompanies human development from antiquity to the present day. The main perceptions of corruption is that it is an undesirable phenomenon which negatively affects society, contributes to the imbalance in the distribution of public goods and adversely affects the economy and society`s confidence in state governance and state`s institutions efficiency. Modern economy is permanently evolving and becoming more interdependent, especially in the age of globalization nevertheless corruption phenomenon still has influence despite the continual strategies for its limitation. Anti-corruption legislation at global, regional and national level is constantly developing and irrespective of the different legal systems and different anti-corruption strategies, it remains a constant in society`s life and influences their growth. At least that is what the first studies results on corruption impact on countries` economies development in the 1960s 1970s of the 20th century have demonstrated. The aim of this research is to assess the corruption impact on the Bulgarian economy, reflecting the contemporary reality in which the Bulgarian business develops its activities. The main research method is the method of the response and for the procession of the information are used statistical methods - method of observation, method of the group, method of the analysis and graphic method. The analysis and conclusions on the problem are based on a data survey, where representatives of the business enterprises from South-West region had an opportunity to answer questions, aimed at revealing the most common corruption practices and how they affect their normal business activity.
\end{abstract}

\section{Introduction}

The concept of corruption is a way of thinking, of lifestyle, of management. It is a constant companion to the development of any society and the governance of public goods. There are hardly any countries where corruption can not be found, there are such countries where it can

*Corresponding author: irina_atanasova@yahoo.com 
be found only at higher levels of governance and countries where it has covered the entire state government.

Although the notion of corruption developed more seriously after 1960 [1, 2], it has always accompanied the development of the societies since their inception and had an impact on the development and the economic growth of the countries. The main concern is that corruption has a negative impact on the economic development $[3,4,5,6,7]$ and it should be limited by the means of adequate legal mechanisms because it leads to misallocation of public goods, which undermines public confidence in the impartiality of state institutions, as well as the public confidence in the legal norms. Another thesis is that corruption can have a positive impact on business, such as on the foreign direct investment $[8,9]$ and to increase the public investment [4], which can lead to raise in the productivity and the economic growth $[10,11,12]$. For example, corruption may facilitate the conclusion of transactions that would otherwise not have taken place because of bureaucratic difficulties, resulting in creating the so called practice of "speed money", which shortens the time required to obtain a specific service $[1,13]$. In this regard it should be noted that the business corrects wrong decisions of the legislative and the executive power [13].

Corruption as a phenomenon undoubtedly exists nowadays. According to many researchers, who have devoted their lives to its study, corruption is a phenomenon that affects on the development and the prosperity of the society [14]. The economic integration of the countries, the development of international trade, the use of international capital, the rapid development of communications brings new global opportunities for the development of the phenomenon "corruption" and makes combating it extremely difficult. Similar is the position of the United Nations, when was adopted the United Nations Convention against Corruption. The foundations on which the Convention was legally constructed are: justice, concern for the stability and security of societies, their sustainable development. The Convention presents the corruption as a form of criminal activity even in the preamble, giving guidelines for the development of anti-corruption legislation of the signatory states.

The attempts concerning the development of a comprehensive definition of the phenomenon "corruption" always end in failure or the crafted definitions have imperfections. This is due to the intricacy of this phenomenon, which combines all those illegal or amoral actions through which individuals, occupying certain positions in the state apparatus, use the power entrusted to them, to gain for themselves or for their close individuals undue benefit. The society identifies this benefit as an active or passive bribery, but in practice corruption has a number of different forms, such as trading an influence, laundering illegal property, illegal acquisition and disposition of property, creating obstacles to justice and much more.

The Bulgarian legislation in the early 2018 adopted a new anti-corruption law to combat corruption and for feiture of illegally acquired property by which introduced a legal definition of "corruption". According to Art. 3, paragraph 1 of the ACCSIAP (Act on counteracting corruption and on seizure of illegally acquired property), "Corruption in the meaning of this act shall exist, where as a result of the occupied high public position, the person abuses with power, violates or fails to perform official obligations in view to direct, or indirect retrieving unreasonable material or intangible benefits for themselves or for other persons." In accordance with this continues to evolve the rest of the anticorruption legislation affecting public procurement, money laundering, tax fraud, etc. The current anti-corruption legislation on the other hand should help to increase the feeling of security for businesses and contribute to the favorable business development, encourage competition, initiative and creativity. Moreover, the continuous development of new products and the search for and absorption of new markets in the dynamically changing market conditions and intense competition are essential characteristics of any enterprise and economy, which seek to expand their influence and hold leadership positions not only locally or nationally, but also globally [15]. It is possible to seen the growth amount of information that are monitored, measured and assessed 
[16]. The business climate in Bulgaria is improving, at present there is growth in the gross domestic product -3.5 percent, incomes are increasing, investment has increased by $2.5 \%$, and the main engine of the economy remains consumption [17]. Based on this data, the level of corruption should be reduced [18] but Corruption Perceptions Index [19] remains relatively constant - 42 for 2018 . In this regard the present survey aims to show the opinion of the businesses about the phenomenon "corruption" and to present certain situations which the business community has faced. Last but not least, it should be pointed out that corruption can increase public investment, but their effectiveness on the economy is negligible [20].

\section{Methodology of the research}

The assessment of the impact of corruption on the sustainable business development in Southwestern Bulgaria is based on the results of a conducted survey among 34 business representatives on the method of the response. The main reason for choosing this method is its adequacy in terms of the specifics of the subjects and the data to be received. Moreover, the method of response is appropriate in terms of fieldwork by the respondents because it helps to provide direct access to respondents through personal and group meetings. The study was conducted during the period March-June 2019.

For the procession of the information are used statistical methods - method of observation, method of the group, method of the analysis and graphic method.

\section{Assessment of the corruption on the sustainable development of the businesses}

In connection with full and accurate disclosure of the issue, we believe that it is necessary to outline the profile of the business in Southwestern Bulgaria.

The results of the analysis of the companies, according to the form of registration shown in figure 1 reveals that the most significant share is the SLTD - Sole Limited Liability Company (73.6\%), followed by LTD - Limited Liability Company (11.8\%) and ST - sole trader $(5.9 \%)$.

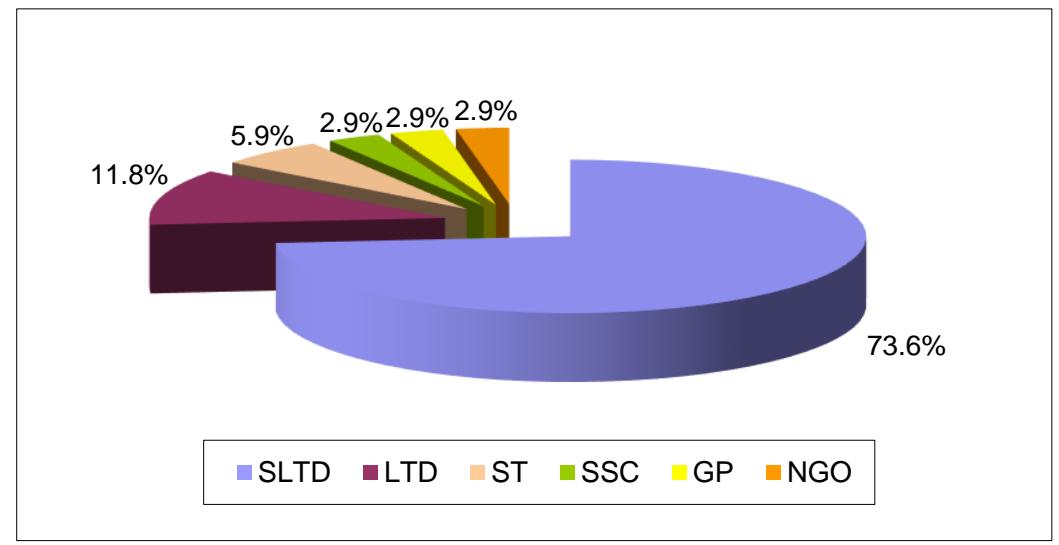

Fig. 1. Distribution of enterprises according to the form of registration - $\%$

An important element of the characteristics of each business is the choice of a sphere of economic activity. The results presented in figure 2 show that the highest proportion of companies are in the sector "trade" and sector "services" - an equal share of $(29.42 \%)$, followed by the sector "tourism" (8.82\%). They are followed by the sectors "transport", "agriculture", "mining and quarrying", "light industry" and "food industry" - 5.88\%. The 
proportion of the surveyed sector "computer and information systems" is unsignificant - only $2.94 \%$.

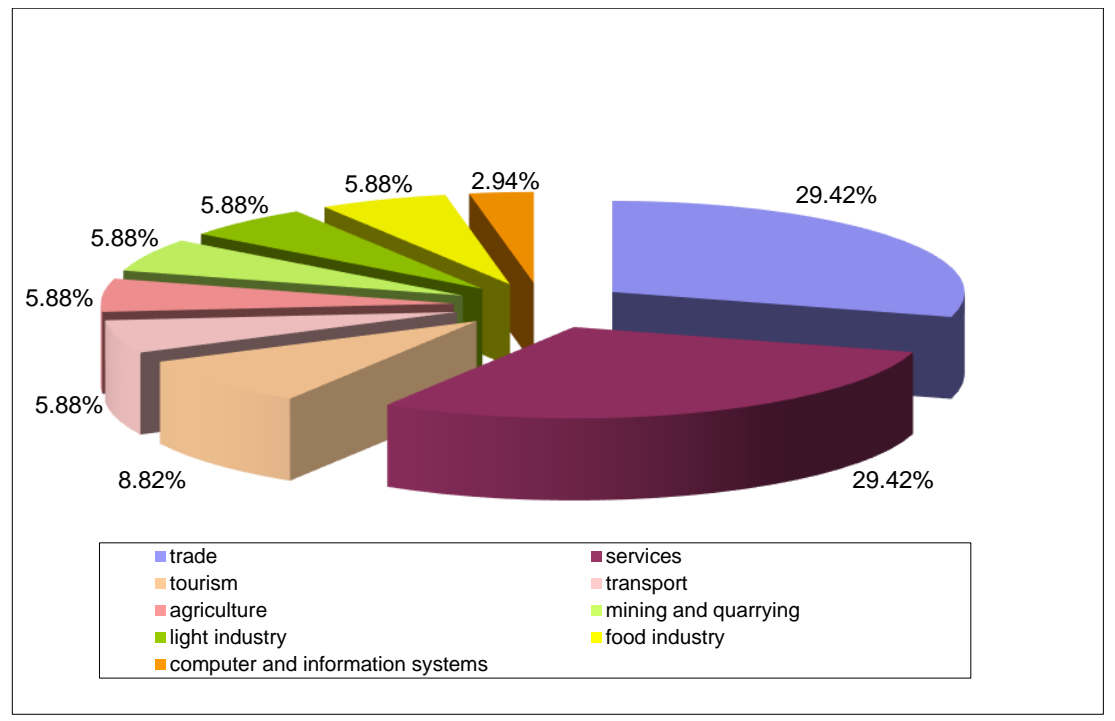

Fig. 2. Distribution of enterprises according to the sphere of economic activity - \%

The obtained results concerning the distribution of the companies, according to their size, shown in figure 3 indicate that the biggest share have the micro enterprises $-76.47 \%$. Significantly smaller is the share of the companies with staff between 10 and 49 persons $17.65 \%$, followed by those with employees from 50 to 249 and 250 - with an equal share of $2.94 \%$.

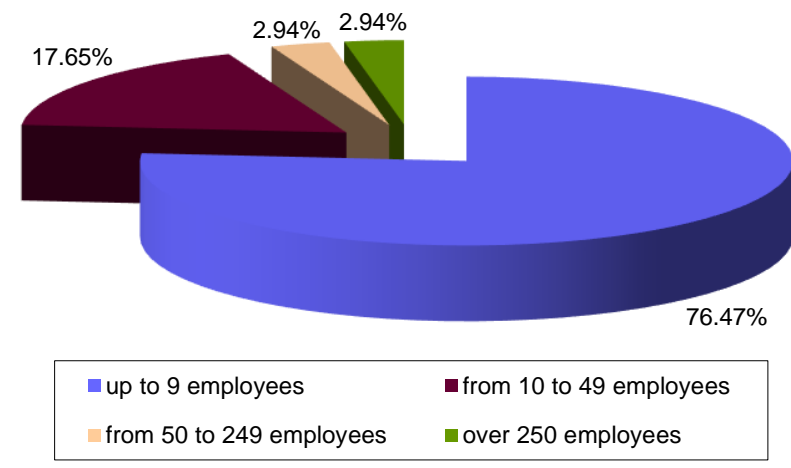

Fig. 3. Distribution of the companies according to their size - \%

One of the important aspects of the study is the opinion of the companies on whether corruption is a threat to their activity (figure 4). The survey results reveal that the largest proportion of the respondents indicated the answer "rather yes" (41.18\%), followed by those who firmly believe that the corruption is a threat to the activity of their businesses $(35.29 \%)$. Relatively low is the proportion of respondents who response "rather no" (14.71\%) and "no" $(5.88 \%)$. Only $2.94 \%$ of the respondents answered "they do not know". 


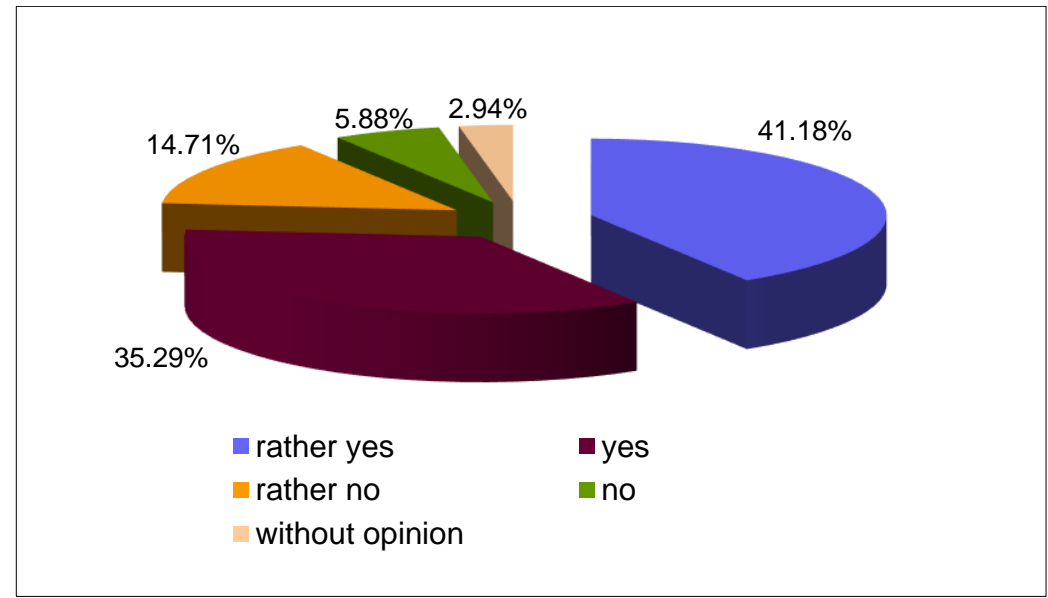

Fig. 4. Distribution of enterprises according to the presence of corruption as a threat to the business activity - \%

Interesting is the view of the respondents regarding the situation where a state or government official requested a bribe (figure 5). It was observed that the largest proportion of respondents did not have such a situation $(61.77 \%)$. Considerably smaller is the proportion of those who have suffered such a situation (26.47\%). Only 11.76 percent of respondents indicated the answer "I do not want to answer."

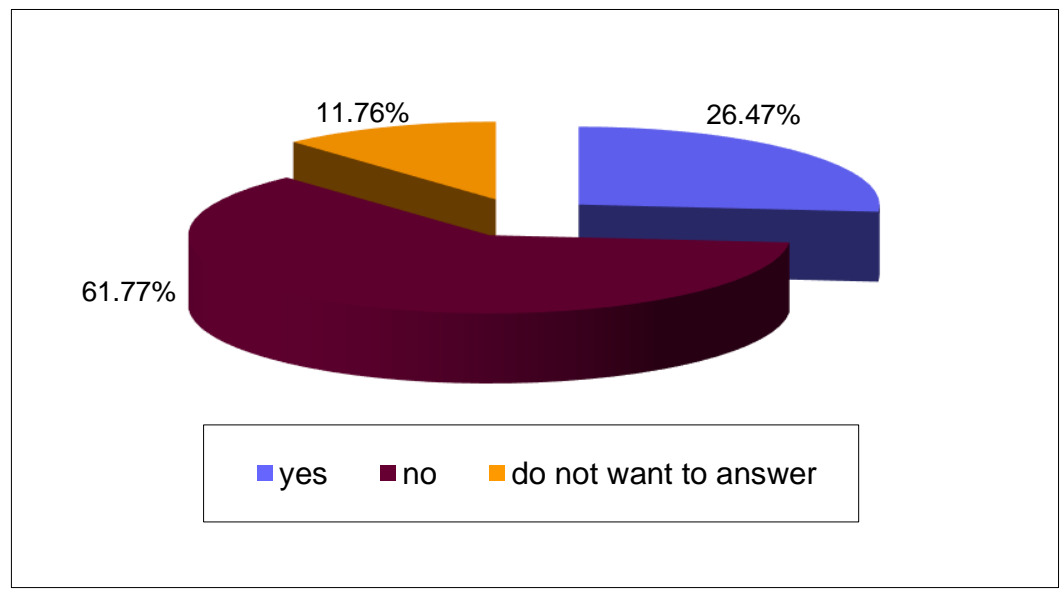

Fig. 5. Distribution of the companies according to the presence of a situation in which a state or government official requested a bribe - \%

Concerning the question "Have you ever given a bribe - from the beginning of your business up to date", $76.47 \%$ of the business representatives say that was not necessary. The similar results are observed in other emerging economies with high corruption levels where not all businesses state they need to pay bribes and there is considerable variation in reported graft across firms facing similar institutions [21]. It is note worthy that the share of those who have given a bribe is not significant $-14.71 \%$. Only $8.82 \%$ of the respondents indicate they do not want to answer.

Also important are the views of the respondents regarding the giving of the requested bribe, and its impact on their business (figure 6). A significant proportion of respondents believe that if they do not give a bribe, this will negatively affect their business $(64.71 \%)$. However, there are such situations where bribery may help innovators in these markets to 
introduce new products by overcoming bureaucratic obstacles [22]. Relatively low proportion of the respondents say that, if they do not give the requested bribe, it will not negatively affect their business (26.47\%). Only $8.82 \%$ of the business representatives respond "I do not want to answer."

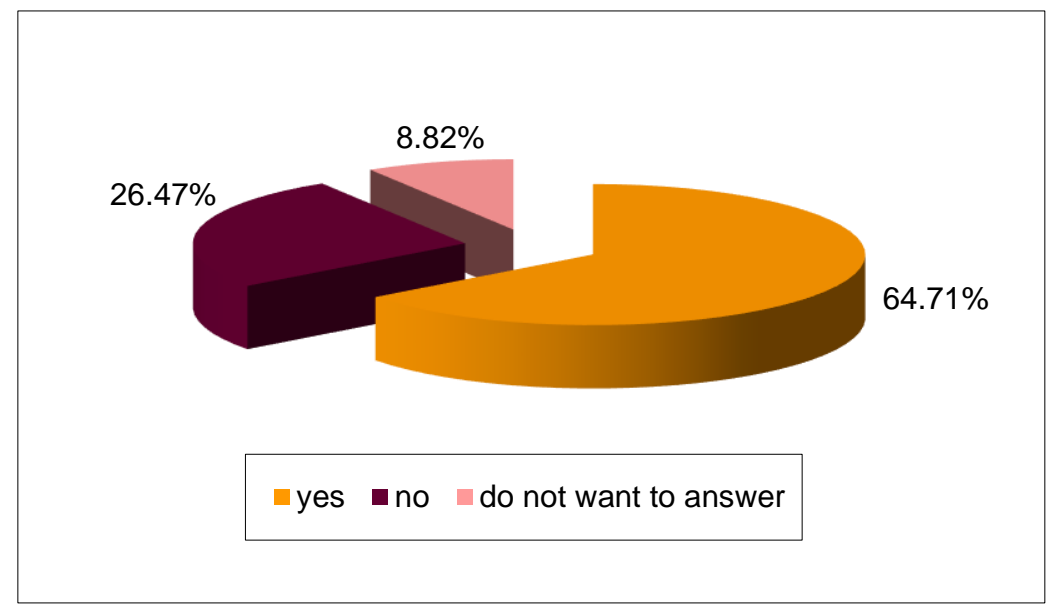

Fig. 6. Distribution of the companies according to how the bribery will affect on the business - $\%$

Another important aspect of the study is the opinion of respondents regarding the information where they can complain or give a signal, if they are victims of corrupt practices. In this regard, the survey data suggest that a significant proportion of respondents do not have such information $(55.88 \%)$. Meanwhile, $44.12 \%$ of the respondents know where they can complain in case of corrupt practice and they mention institutions such as the police, prosecution, and also the Commission for counteracting corruption and for seizure of illegally acquired property.

\section{Conclusion}

Based on the results of the survey on the impact of corruption on sustainable business development in Southwestern Bulgaria, the following conclusions can be made:

- most respondents believe that corruption exists and that it is a threat to their business;

- the proportion of respondents, who were in a situation in which a state official requested a bribe from them is not small;

- $\quad$ it appears that the proportion of business representatives who have had to give a bribe - from starting the business up to date is not big, but nevertheless such situations exists;

- there is a significant proportion of respondents who believe that if they do not give the bribe requested, it will adversely affect their business;

- $\quad$ it is found that more than half of the respondents do not have information to whom they can complain, if they are victims of corruption practices.

The literature review, as well as the results of the survey, show that corruption has a negative impact on the business as a whole. Based on the answers provided, it can be concluded that the business is operating in an uncertain business environment, where the phenomenon corruption is evident from the results. This uncertainty stems from the fact that a large number of respondents are not sure who to complain in order to receive adequate protection, which in turn leads to the conclusion that they are not familiar with the current anti-corruption legislation in the country and the EU. The concerns that if a bribe is not given, 
it could affect the business, gives a signal for an existing distrust of the anti-corruption legislation and the belief that those who have requested the bribe will not receive an adequate punishment. The obtained results are based on the experience and the internal feeling of the respondents, which leads to the conclusion that there is a need to work on both sides to create mutual trust, which can only be achieved with well-drafted anti-corruption legislation and a clear and definitive position of the business against corruption. If only one side has hesitations, then will the actions against corruption be fictitious and will have a negative impact on our country's much-desired economic development and EU support.

It is only the values and the moral of each of us to be the invisible barrier to the development of the corruption. However, this is only valid in a well established and functioning mechanism for the protection of the individuals who have to make decisions in state and in public interest. If this mechanism is distorted, then no matter how high is the moral of the state officials, the insecurity and the fear of future negative consequences for them or related persons, can have a significant impact in their decision making. In this regard, measures such the adoption of a new anti-corruption regulation; addressing weaknesses in the investigation and prosecution of high-level corruption cases; introducing risk-based anticorruption measures at the lower levels of government; setting up a mechanism for publicly reporting progress on the implementation of the national anti-corruption strategy should reduce the feeling of insecurity of the business.

\section{References}

1. N. Leef, Economic Development through Bureaucratic Corruption, American Behavioral Scientist, 8-14 (1964)

2. S. Huntington, Political Order in Changing Societies, New Haven, CT: Yale University Press, (1968)

3. C. Leite, J. Weidmann. Does Mother Nature Corrupt? Natural Resources, Corruption, and Economic Growth, IMF Working Papers WP/96/85 (1999)

4. I. Ehrlich, F. Lui, Bureaucratic Corruption and Endogenous Economic Growth. Journal of Political Economy, 107 (6), 270-293 (1999)

5. P. Mauro, Corruption and Growth, The Quarterly Journal of Economics, 681-712 (1995)

6. P. Rodriguez, K. Uhlenbruck, L. Eden, Government corruption and the entry strategies of multinationals, Academy of Management Review, 30 (2), 383-396 (2005)

7. V. Tanzi, Corruption Around the World: Causes, Consequences, Scope and Cures, IMF Working Papers WP/96/63 (1998)

8. P. Egger, H. Winner, Evidence on corruption as an incentive for foreign direct investment. European Journal of Political Economy 21, 932-952. (2005)

9. A. Cuervo-Cazurra, Who cares about corruption? Journal of International Business Studies. November, 37 (6), 807-822 (2006)

10. K. Futagami, Y. Morita, A. Shibata, Dynamic analysis of an endogenous growth-model with public capital. Scandinavian journal of economics, 95 (4), 607-625 (1993)

11. P. Cashin, Government spending, taxes, and economic-growth. International monetary fund staff papers, 42 (2), 237-269 (1995)

12. RJ. Barro, Government spending in a simple model of endogenous growth. Journal of political economy, 98 (5), 103-125 (1990)

13. T. Aidt, Corruption, institutions, and economic development. Oxford Review of Economic Policy, 25 (2), 271-291 (2009) 
14. N. M. Jensen, Q. L. Rahman, Understanding corruption and firm responses in crossnational firm-level surveys, Journal of International Business Studies, 41 (9), 14811504 (2010)

15. V. Kyurova, Assessment of the innovation activity of the entrepreneurial business, Economics and Management, 9 (3), p. 20 (2013)

16. http://www.nsi.bg/bg

17. P. Durana, The use of assessment of work performance of human resources as a tool of management accounting to result controls in Slovak companies. New Trends in Finance and Accounting, (Springer, Cham) 571-579 (2017)

18. D. Treisman, What Have We Learned about the Causes of Corruption from Ten Years of Cross-National Empirical Research? Annual Review of Political Science, 10, 211-244, (2007)

19. http://transparency.bg/wpcontent/uploads/2019/01/Corruption_Perception_Index_2018_TI_BG_All.pdf

20. M. Haque, R. Kneller, Why does Public Investment Fail to Raise Economic Growth? The Role of Corruption. The Manchester School, 83 (6), 623-651 (2015)

21. J. Svensson, Who Must Pay Bribes and How Much? Evidence from a Cross Section of Firms. The Quarterly Journal of Economics, 118 (1), 207-230 (2003)

22. M. Sorin, S. Krammer. Greasing the Wheels of Change: Bribery, Institutions, and New Product Introductions in Emerging Markets. Journal of Management, 45 (5), 1889-1926 (2017) 